\title{
Caucasian clover was more productive than white clover in grass mixtures under drought conditions
}

\author{
A.D. BLACK ${ }^{1}$ and R.J. LUCAS \\ Soil, Plant and Ecological Sciences Division, PO Box 84, Lincoln University, Canterbury \\ 1Blacka1@lincoln.ac.nz
}

\section{Abstract}

This experiment compared the productivity of caucasian or white clover when established with five perennial grass species over 6 years in a dry lowland environment. Hexaploid 'Endura' caucasian clover or 'Grasslands Demand' white clover were sown in December 1994 with high endophyte 'Yatsyn' perennial ryegrass, 'Grasslands Wana' cocksfoot, 'Grasslands Advance' tall fescue, 'Grasslands Gala' grazing brome, or 'Grasslands Maru' phalaris into a deep, fertile silt loam. Initial establishment of clovers was poor with ryegrass and grazing brome. Some volunteer white clover established in all 10 treatments. After the first 14 months, no irrigation was applied over the following 4 years. Sheep grazed plots about six times each year. The legume cover in 15-month-old pastures was higher when sown with white clover (29\%) than caucasian clover $(21 \%)$ but dry conditions during 1997/1998 (60\% of $680 \mathrm{~mm}$ mean annual rainfall) and 1998/1999 (66\% of mean rainfall) decreased the percentage of legume in white clover pastures. In February 1998 and March 1999 , legume contributed $37 \%$ and $21 \%$ of the dry matter (DM) in caucasian clover pastures, but only $4 \%$ and $1 \%$ in pastures sown with white clover. Rainfall during the sixth season (1999/2000) was more favourable (111\% of mean rainfall). Total DM production from July 1999 to June 2000 was 10.0 t DM/ha from caucasian clover pastures and $8.7 \mathrm{t} \mathrm{DM} /$ ha from pastures sown with white clover. The mean proportion of legume in white clover pastures ranged from $9 \%$ when sown with ryegrass and phalaris to $1 \%$ with cocksfoot. In contrast, mean caucasian clover legume contents were similar across all grass treatments at $20 \%$, but reached $46 \%$ with cocksfoot during summer. It was concluded that caucasian clover is more tolerant of summer moisture stress than white clover when in association with perennial grass species.

Keywords: botanical composition, Bromus stamineus, Dactylis glomerata, legume content, Lolium perenne, moisture stress, pasture production, Phalaris aquatica, Schedonorus phoenix syn. Festuca arundinacea, Trifolium ambiguum, T. repens

\section{Introduction}

Caucasian clover (Trifolium ambiguum) is well adapted to fertile South Island rangeland (Woodman et al. 1992; Allan \& Keoghan 1994; Scott 1998) and may prove valuable in lowland intensive farming systems where white clover (Trifolium repens) suffers abiotic and/or biotic stress. For instance, on light volcanic soils in coastal Bay of Plenty, Watson et al. (1998) showed that caucasian clover survived summer drought better than white clover.

Where perennial grass competition presents the major stress on pasture legumes, caucasian clover has also been more productive than white clover. In a range of irrigated grass/clover mixtures in Canterbury, Moss et al. (1996) reported slower establishment by caucasian clover compared with white clover but after 2 years caucasian clover pastures contained more legume than the five white clover/grass mixtures. Also in Canterbury, Black et al. (2000) have shown that caucasian clover/ryegrass pastures can produce more legume than white clover/ryegrass where soil moisture stress was eliminated by irrigation.

The field experiment reported in this paper was established to compare the competitive abilities of caucasian clover or white clover against the same five perennial grass species used by Moss et al. (1996). But in our experiment, the effect of moisture stress was investigated. Irrigation, to assist clover establishment, was applied in the first two summers after a late December 1994 sowing. No irrigation was applied subsequently. This 14-month establishment period was followed by 3 years with less than average rainfall and then a sixth year (1999/2000) with average rainfall. The objective was therefore to compare the competitive abilities of caucasian clover or white clover against five perennial grass species in a fertile lowland Canterbury environment without irrigation.

\section{Materials and methods}

The experiment at Lincoln University was sown on 20 December 1994 with three replicates of a split-plot 
design. 'Endura' caucasian clover $(6 \mathrm{~kg} / \mathrm{ha})$ or 'Grasslands Demand' white clover ( $3 \mathrm{~kg} / \mathrm{ha}$ ) were sown as main plots with five perennial grass species ('Yatsyn' perennial ryegrass (Lolium perenne) infected with wild type endophyte (Neotyphodium lolii) $(16 \mathrm{~kg} / \mathrm{ha})$, 'Grasslands Wana' cocksfoot (Dactylis glomerata) (6 $\mathrm{kg} / \mathrm{ha}$ ), 'Grasslands Advance' tall fescue (Schedonorus phoenix syn Festuca arundinacea) $(20 \mathrm{~kg} / \mathrm{ha})$, 'Grasslands Gala' grazing brome (Bromus stamineus) (30 kg/ha), and 'Grasslands Maru' phalaris (Phalaris aquatica) $(10 \mathrm{~kg} / \mathrm{ha}))$ as sub plots. The caucasian clover seed was inoculated with the specific Rhizobium strain ICC105 (Pryor et al. 1998). Grass sub-plots were $9 \mathrm{x}$ $2.1 \mathrm{~m}$.

The deep Wakanui silt loam was fallowed in spring/ early summer before sowing and had a soil water holding capacity of $200 \mathrm{~mm}$ to a depth of $600 \mathrm{~mm}$ (K.M. Pollock pers. comm.). Plots were irrigated (about $100 \mathrm{~mm}$ ) during establishment in the summers of 1994/ 1995 and 1995/1996, but received no further irrigation after the first 14 months. No fertiliser has been applied since sowing but a soil test in March 1996 indicated high soil fertility ( $\mathrm{pH}$ 6.1, Olsen $\mathrm{P}$ 39). Sheep rotationally grazed the experiment about six times each year and plots were mown to a residual height of $40 \mathrm{~mm}$ after each grazing.

\section{Measurements}

Legume cover in March 1996 was determined by point analysis (Webb 1996). Dry matter production was determined before grazing after 7 weeks regrowth in February 1998 (Garb 1998) and March 1999, and after five 7- to 10-week-regrowth periods from July 1999 to June 2000. At each harvest, herbage was cut to $40 \mathrm{~mm}$ above ground level within two $\mathrm{x} 0.2 \mathrm{~m}^{2}$ quadrats per plot and sub-samples were dissected to determine botanical composition before drying.

\section{Statistical analysis}

Significant $(\mathrm{P}<0.05)$ treatment differences were determined using two-way analysis of variance according to the split-plot design and standard errors of means are presented. Legume content data were arcsine transformed when necessary.

\section{Results}

\section{Rainfall}

Rainfall in 1994/1995 averaged $90 \mathrm{~mm}$ per season (57\% of the $158 \mathrm{~mm}$ long-term mean) over the three seasons spring (September-November), summer (DecemberFebruary) and autumn (March-May) (Table 1). Spring-summer-autumn 3-month seasonal rainfalls averaged $137 \mathrm{~mm}(87 \%)$ in 1996/1997, $84 \mathrm{~mm}(53 \%)$ in $1997 / 1998,104 \mathrm{~mm}(66 \%)$ in $1998 / 1999$ and $163 \mathrm{~mm}(103 \%)$ in $1999 / 2000$. In general, potential evapotranspiration exceeded rainfall for 8 months of the year (September-April) over the 6 years.

Table 1 Rainfall $(\mathrm{mm})$ at Lincoln during winter (June-August), spring (September-November), summer (DecemberFebruary), and autumn (March-May), from 1994/19951999/2000 and long-term average (1975-1991) rainfall and evapotranspiration (mm).

\begin{tabular}{lcrrrc}
\hline & Winter & \multicolumn{5}{c}{ Spring } & Summer & Autumn & Annual Total \\
\hline $1994 / 1995$ & 177 & 98 & 82 & 89 & 446 \\
$1995 / 1996$ & 225 & 153 & 64 & 159 & 601 \\
$1996 / 1997$ & 215 & 86 & 171 & 155 & 627 \\
$1997 / 1998$ & 157 & 81 & 73 & 97 & 408 \\
$1998 / 1999$ & 134 & 97 & 99 & 116 & 446 \\
$1999 / 2000$ & 262 & 138 & 140 & 212 & 752 \\
& \multicolumn{5}{l}{ Long-term means (1975-1991) } \\
Rainfall & 205 & 151 & 163 & 161 & 680 \\
Evapotran- & & \multicolumn{5}{c}{} \\
spiration & 121 & 297 & 413 & 203 & 1034 \\
\hline
\end{tabular}

\section{Establishment}

Initial establishment of four grass species was excellent but cocksfoot and clover species had low seedling populations. Clover populations were lowest in ryegrass and grazing brome treatments. Caucasian clover had populations of only four seedlings $/ \mathrm{m}^{2}$ when sown with grazing brome. Subsequently, clovers spread by rhizomes or stolons and resulted in legume presence throughout most plots after 2 years. Some volunteer white clover established in all 10 treatments.

\section{Dry matter production}

In February 1998, the amount of DM produced after 7 weeks regrowth was greater $(\mathrm{P}<0.05)$ from pastures sown with caucasian $(1.2 \mathrm{t} \mathrm{DM} / \mathrm{ha})$ than white clover (0.8 t DM/ha) 3 years after sowing (Table 2). At this stage, DM production differed $(\mathrm{P}<0.05)$ across grass treatments independent of clover species. Cocksfoot produced the most (1.2 $\mathrm{t} \mathrm{DM} / \mathrm{ha}$ ) compared with grazing brome, which produced the least $(0.8 \mathrm{t} \mathrm{DM} / \mathrm{ha})$. In March 1999 (4 years after sowing), DM production after 7 weeks was similar between clover species $(2.2 \mathrm{t}$ $\mathrm{DM} / \mathrm{ha})$, but differed $(\mathrm{P}<0.05)$ across grass treatments. Cocksfoot pastures again produced more $(\mathrm{P}<0.05)$ herbage (2.4 t DM/ha) than the other four grasses $(2.1 \mathrm{t}$ $\mathrm{DM} / \mathrm{ha}$ ) independent of clover species.

During the sixth year (1999/2000), total DM production from July 1999 to June 2000 averaged $10.0 \mathrm{t} \mathrm{DM} / \mathrm{ha}$ from caucasian clover pastures and $8.7 \mathrm{t}$ $\mathrm{DM} /$ ha from pastures sown with white clover (Table 2), but was only significantly different between clover species in February 2000 (2.6 vs. 1.8 t DM/ha). Pastures 
Table 2 Dry matter production (t DM/ha) from pastures sown in December 1994 with caucasian or white clovers and five perennial grass species after 7 weeks regrowth in February 1998 and March 1999, and from five 7- to 10-week harvests from July 1999 to June 2000 .

\begin{tabular}{|c|c|c|c|c|c|c|c|}
\hline \multirow[t]{2}{*}{ Date } & \multirow[t]{2}{*}{ Clover } & \multicolumn{5}{|c|}{ Companion Grass - } & \multirow[t]{2}{*}{ SEM } \\
\hline & & Cocksfoot & Ryegrass & Grazing brome & Phalaris & Tall fescue & \\
\hline \multirow[t]{2}{*}{ Feb 1998} & Caucasian & 1.5 & 1.1 & 0.8 & 1.2 & 1.4 & \multirow[t]{2}{*}{0.15} \\
\hline & White & 0.9 & 0.7 & 0.8 & 0.9 & 0.7 & \\
\hline \multirow[t]{2}{*}{ Mar 1999} & Caucasian & 2.5 & 2.2 & 2.2 & 1.9 & 2.2 & \multirow[t]{2}{*}{0.09} \\
\hline & White & 2.3 & 2.1 & 2.1 & 2.1 & 2.1 & \\
\hline Jul 1999 & Caucasian & 10.6 & 9.5 & 10.4 & 10.6 & 9.0 & 0.57 \\
\hline -Jun 2000 & White & 10.3 & 8.4 & 8.7 & 9.1 & 7.3 & \\
\hline
\end{tabular}

produced the most $(\mathrm{P}<0.05)$ total $\mathrm{DM}$ when sown with cocksfoot (10.4 t DM/ha) and the least with tall fescue (8.2 t DM/ha) regardless of clover species.

\section{Legume content}

The percentage of legume cover in pastures at 15 months of age in March 1996 was higher $(\mathrm{P}<0.05)$ when sown with white clover $(29 \%)$ than caucasian clover $(21 \%)$ (Table 3$)$. The percentage of white clover then declined in all pastures over the following 23 months so that in February 1998, legume contributed $37 \%$ of the DM in caucasian clover pastures, but only $4 \%$ in pastures sown with white clover $(\mathrm{P}<0.05)$. Caucasian clover pastures at 4 years of age in March 1999 continued to produce more $(\mathrm{P}<0.05)$ legume (21\%) than pasture sown with white clover (1\%).

When sown with caucasian clover, 15-month-old cocksfoot and phalaris pastures averaged $27 \%$ legume cover, compared with $17 \%(\mathrm{P}<0.05)$ for ryegrass, grazing brome and tall fescue (Table 3 ). In February 1998 , legume contributed $41 \%$ of the DM in grass treatments other than grazing brome with $22 \%$ legume $(\mathrm{P}<0.05)$. Similarly in March 1999, phalaris and ryegrass pastures contained the most legume (27\%) and tall fescue and grazing brome the least (15\%) 4 years after sowing $(\mathrm{P}<0.05)$.

In white clover pastures, legume cover exceeded $40 \%$ with phalaris compared with $26 \%(\mathrm{P}<0.05)$ for the other four grass species in March 1996 (Table 3).
But in February 1998 and March 1999, the contribution of legume to production was uniformly low with all five grass species. For instance in March 1999, white clover was absent from pasture sown with cocksfoot, compared with $23 \%$ legume when cocksfoot was sown with caucasian clover $(\mathrm{P}<0.05)$.

During the sixth year (1999/2000), pastures continued to produce more $(\mathrm{P}<0.05)$ legume when sown with caucasian clover (20\%) than white clover (7\%) (Figure 1). The legume content of caucasian clover pastures was similar across all grass treatments, but in February reached $46 \%$ with cocksfoot compared with only $2 \%$ when cocksfoot was sown with white clover $(\mathrm{P}<0.05)$. However in February, phalaris $(18 \%)$, ryegrass $(16 \%)$ and tall fescue $(15 \%)$ pastures each contained more $(\mathrm{P}<0.05)$ white clover than pastures sown with cocksfoot.

Volunteer white clover contributed $23 \%$ of the total legume produced in caucasian clover pastures during spring 1999 and autumn 2000, but only $10 \%$ of the total legume produced in December 1999 and February 2000.

\section{Discussion}

In irrigated pastures in Canterbury, caucasian clover demonstrated superior productivity over white clover when sown with a range of perennial grasses (Moss et al. 1996). The present experiment indicates caucasian

Table 3 Legume content of pastures sown in December 1994 with caucasian or white clovers and five perennial grass species as percentage of total legume cover in March 1996, and percentage total legume of dry matter produced in February 1998 and March 1999.

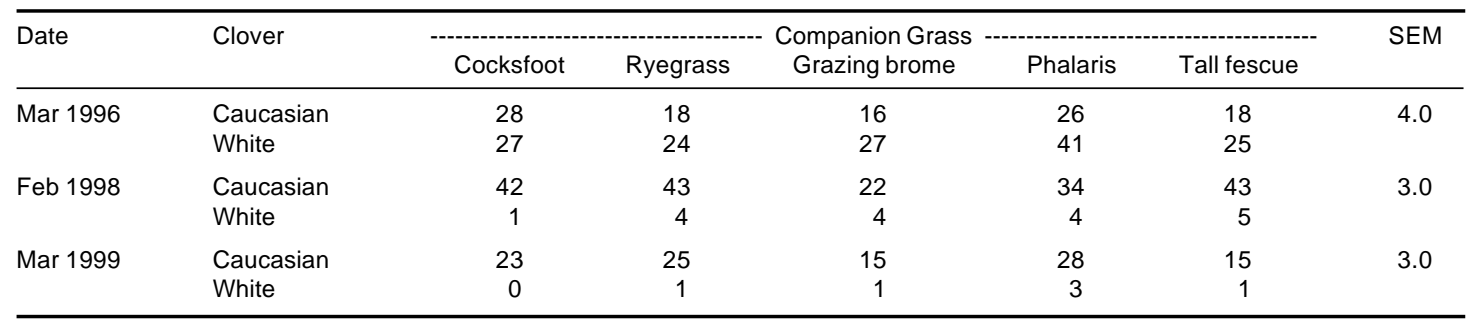


clover can also make a major contribution to the legume content of unirrigated pastures sown with the same perennial grass species used by Moss et al. (1996). The large difference in legume content observed between the two clover pastures in this experiment appeared to be largely owing to the weakness of white clover during summer drought.

The percentage of legume in pastures sown with white clover decreased dramatically when rainfall averaged only $53 \%$ of the mean during spring-summer-autumn of 1997/1998. In contrast, the legume content of caucasian clover pastures increased over time after poor initial clover establishment. This resulted in greater DM production from caucasian than white clover pastures at 3 years of age, and contributed to the extra $1.3 \mathrm{t} \mathrm{DM} /$ ha total DM from caucasian clover pastures in the sixth year (1999/2000). This more favourable season, when annual rainfall was $111 \%$ of the mean, enabled white clover pastures to reach $18 \%$ legume in February 2000. In contrast, the percentage of legume in pastures sown with caucasian clover reached $46 \%$.

Periodic moisture stress is a major constraint to the production of high quality forage in conventional white clover-based pastures in many parts of New Zealand, particularly in dry hill country and along the east coast (Williams et al. 1990). Hot dry summers, leading to soil surface temperatures lethal to white clover stolons and crowns (Watson et al. 1995), can severely reduce and delay the recovery of white clover as demonstrated in the present experiment. Much effort has been made to improve the tolerance of white clover to moisture stress through recurrent selection for greater tap-root diameter (Woodfield \& Caradus 1987; Woodfield et al. 1995) and water use efficiency (Barbour et al. 1995). However, an extensive root system (Speer \& Allinson 1985; Strachan et al. 1994) and protected underground growing points, has made caucasian clover an attractive alternative to white clover in drought prone coastal Bay of Plenty (Watson et al. 1997) and lower slopes of the South Island high country (Chapman et al. 1989; Woodman et al. 1992).
Figure 1 Botanical composition of pastures sown in December 1994 with caucasian or white clovers and five perennial grass species from July 1999 to June 2000.

\section{Caucasian clover}
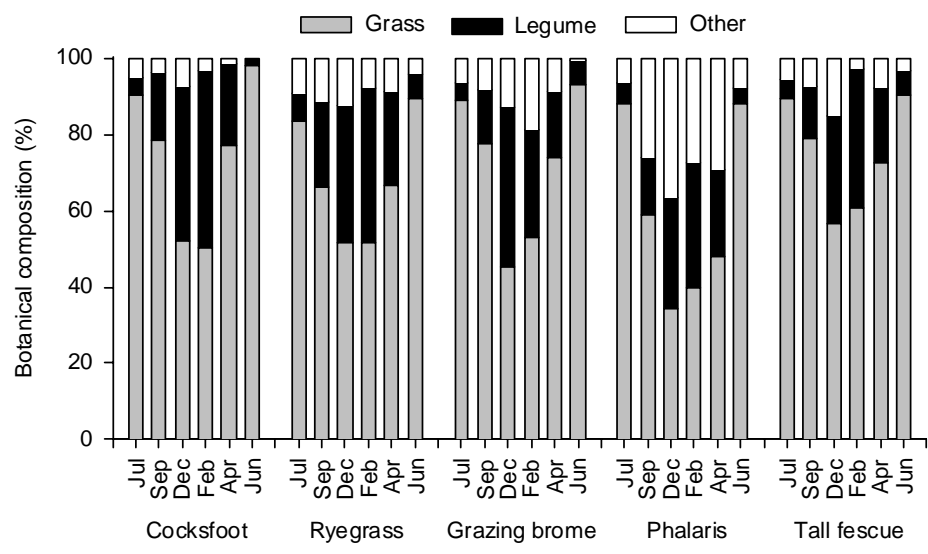

White clover

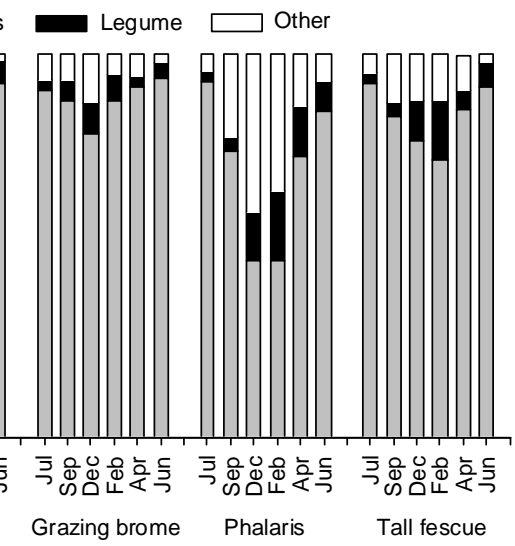

The volunteer white clover (probably 'Huia' establishing from buried hard seed) in the caucasian clover-based pastures contributed about $20 \%$ in spring and autumn but only $10 \%$ in summer to their superior total legume production. This mixture of clovers represents what is most likely to happen even where caucasian clover is sown without white clover because of the widespread presence of white clover seed in New Zealand pastoral lands. Elliot et al. (1998) discussed the possibility of poor sociability between caucasian and white clover because of rhizobial incompatibility. However, in this and other experimental sowings (e.g., Black et al. 2000; Moss et al. 1996; Watson et al. 1996), caucasian clover has appeared to be complementary rather than competitive towards white clover.

Caucasian clover-based pastures produced a greater proportion of legume than white clover across all grass 
species. However, the most important specific result was the dramatic difference in legume content between clover treatments in pastures sown with cocksfoot. Cocksfoot has a reputation as a very aggressive grass species in fertile lowland environments, where the suppression of high quality companion grasses and clovers has resulted in poor grass productivity and palatability (Moloney 1995). After more than 5 years of association, the total legume content of cocksfoot/ caucasian clover pastures in February 2000 (46\%) was superior to that based on white clover (2\%). If caucasian clover can be established it is likely to improve the nutritive value of pastures in many dryland environments where cocksfoot is the most persistent grass species.

Grass grub damage in ryegrass pastures during 1998/1999 and 1999/2000 limited production but created space for annual grass weed species to establish. Consequently in February 2000, the percentage of white clover in ryegrass $(16 \%)$ pasture was similar to that in tall fescue $(15 \%)$ and phalaris $(18 \%)$ pastures, which generally have an erect open canopy structure favourable for white clover growth. In contrast, grazing brome was less sociable with white clover, which may have been owing to its relative unsuitability to the rotational grazing applied in this study (A. Stewart pers. comm.).

The total dry matter yield of $10 \mathrm{t} \mathrm{DM} / \mathrm{ha}$ reached from pastures in 1999/2000 compared unfavourably with $19 \mathrm{t} \mathrm{DM} /$ ha from 3-year-old dryland lucerne during the same year on the same soil type in an adjacent area at Lincoln University (D.J. Moot pers. comm.). In the very dry 1998/1999 season, the 2-year-old lucerne without irrigation produced $21 \mathrm{t} \mathrm{DM} /$ ha but the annual pasture production from our experiment would have been much less than the $10 \mathrm{t} \mathrm{DM} /$ ha achieved during a slightly wetter than average 1999/2000 year. These yields from the deep and fertile Wakanui silt loam would suggest that lucerne should be grown wherever possible in the summer dry Canterbury plains environment. Unfortunately, it is very difficult to manage a pastoral farm with more than $50 \%$ of the area planted in lucerne. The balance of these properties will normally be in grass/clover pastures with a limited area of winter forage. It is therefore very important that efforts are continued in the search for persistent high quality pasture species for dryland areas.

\section{Conclusions}

The present experiment indicates caucasian clover can make a significant contribution to the productivity and nutritive value of dryland grass/clover pastures in subhumid environments. Specific conclusions were:
1. Once established, caucasian clover will enhance the proportion of total legume produced in lowland pastures.

2. Caucasian clover is more tolerant of dry soil conditions than white clover.

3. Caucasian clover is much more compatible with 'Wana' cocksfoot than white clover.

4. Conventional grass/clover pastures are relatively low yielding compared with lucerne in the subhumid areas of New Zealand.

\section{ACKNOWLEDGEMENTS}

The C. Alma Baker and Struthers Trusts for providing A.D. Black with financial support from post-graduate scholarships.

\section{REFERENCES}

Allan, B.E.; Keoghan, J.M. 1994. More persistent legumes and grasses for oversown tussock country. Proceedings of the New Zealand Grassland Association 56: 143-147.

Barbour, M.; Caradus, J.R.; Woodfield, D.R.; Silvester, W.B. 1995. Water stress and water use efficiency of ten white clover cultivars. White Clover: New Zealand's Competitive Edge. Agronomy Society of New Zealand Special Publication 11/Grassland Research and Practice Series 6: 159-162.

Black, A.D.; Pollock, K.M.; Lucas, R.J.; Amyes, J.M.; Pownall, D.B.; Sedcole, J.R. 2000. Caucasian clover/ ryegrass produced more legume than white clover/ ryegrass pastures in a grazed comparison. Proceedings of the New Zealand Grassland Association 62: 69-74.

Chapman, H.P.; Keoghan, J.M.; Cossens, C.G.; Allan, B.E.; Littlejohn, R.P. 1989. Promising pasture species for drought prone slopes in the South Island high country. Proceedings of the Agricultural Society of New Zealand 19: 77-84.

Elliot, R.M.; McIntyre, H.J.; Challis, B.C., Pryor, H.N.; Lowther, W.L.; Ronson, C.W. 1998. Rhizobium issues affecting the contribution of caucasian clover to New Zealand pastoral agriculture. Proceedings of the New Zealand Grassland Association 60: 207211.

Garb, R.M. 1998. Autumn yield of caucasian and white clover pastures under irrigated and drought conditions. B. Agr. Sc. Honours Dissertation. Lincoln University.

Moloney, S.C. 1995. Selection, management and use of cocksfoot cultivars in North Island pastoral farming. Proceedings of the New Zealand Grassland Association 55: 119-125. 
Moss, R.A.; Burton, R.N.; Allan, B.E. 1996. Productivity of caucasian clover based pastures under irrigation. Proceedings of the New Zealand Grassland Association 58: 177-181.

Pryor, H.N.; Lowther, W.L.; McIntyre, H.J.; Ronson, C.W. 1998. An inoculant Rhizobium strain for improved establishment and growth of hexaploid Caucasian clover (Trifolium ambiguum). New Zealand Journal of Agricultural Research 41: 179189.

Scott, D. 1998. Sixteen years of caucasian clover under contrasting managements. Proceedings of the New Zealand Grassland Association 60: 115-118.

Speer, G.S.; Allinson, D.W. 1985. Kura clover (Trifolium ambiguum): legume for forage and soil conservation. Economic Botany 39: 165-176.

Strachen, D.E.; Nordmeyer, A.H.; White, J.G.H. 1994. Nutrient storage in roots and rhizomes of hexaploid caucasian clover. Proceedings of the New Zealand Grassland Association 56: 77-99.

Watson, R.N.; Harris, S.L.; Bell, N.L. Neville, F.J. 1995. Deferred grazing to enhance white clover content in pastures. White Clover: New Zealand's Competitive Edge. Agronomy Society of New Zealand Special Publication 11/Grassland Research and Practice Series 6: 154.

Watson, R.N.; Neville, F.J.; Bell, N.L. 1998. Caucasian clover performance in a year of severe drought. Proceedings of the New Zealand Grassland Association 60: 119-125.

Watson, R.N.; Neville, F.J.; Bell, N.L.; Harris, S.L. 1996. Caucasian clover as a pasture legume for dryland dairying in the coastal Bay of Plenty. Proceedings of the New Zealand Grassland Association 58: 183-188.

Watson, R.N.; Neville, F.J.; Bell, N.L.; Harris, S.L. 1997. Caucasian clover for improving summer production in northern regions of New Zealand. Proceedings of the New Zealand Grassland Association 59: 227-232.

Webb, A.M.C. 1996. Competitive ability of Caucasian clover (Trifolium ambiguum) compared with white clover (Trifolium repens) on lowland and high country sites. B. Agr. Sc. Honours Dissertation. Lincoln University.

Williams, W.M.; Sheath, G.W.; Chapman, D.F. 1990. Evaluation of clovers in dry hill country 1. General objectives and description of sites and plant material. New Zealand Journal of Agricultural Research 33: 521-526.

Woodfield, D.R.; Caradus, J.R. 1987. Adaptation of white clover to moisture stress. Proceedings of the New Zealand Grassland Association 48: 143-145.

Woodfield, D.R.; Caradus, J.R.; Cousins, G.R.; Dunn, T. 1995. Response to selection for increased taproot diameter. White Clover: New Zealand's Competitive Edge. Agronomy Society of New Zealand Special Publication 11/Grassland Research and Practice Series 6: 141-143.

Woodman, R.F.; Keoghan, J.M.; Allan, B.E. 1992. Pasture species for drought-prone lower slopes in the South Island high country. Proceedings of the New Zealand Grassland Association 54: 115-120. 